\author{
WIESŁAW BUJAKOWSKI*, ANTONI BARBACKI**1 , MACIEJ MIECZNIK*, LESZEK PAJĄK**, \\ ROBERT SKRZYPCZAK*
}

\title{
A STRUCTURAL-THERMAL MODEL OF THE KARKONOSZE PLUTON (SUDETES MOUNTAINS, SW POLAND) FOR HOT DRY ROCK (HDR) GEOTHERMAL USE
}

\author{
MODEL STRUKTURALNO-TERMICZNY PLUTONU KARKONOSZY (SUDETY, POLSKA SW) \\ W KONTEKŚCIE TECHNOLOGII WYKORZYSTANIA CIEPLA GORĄCYCH SUCHYCH SKAL (HDR)
}

\begin{abstract}
The main objective of this study was to develop a spatial temperature distribution of the Karkonosze Pluton to indicate optimum locations for HDR systems at drillable depth.

HDR geothermal technology makes it possible to extract heat from the Earth in areas where no hydrogeothermal resources are present. To produce electricity in a binary cycle, system temperatures of $>100^{\circ} \mathrm{C}$ are usually required. In this paper, the authors have analysed the potential opportunities for applying HDR technology in the area of the Karkonosze Pluton, which is regarded as an optimum location for the application of the HDR concept (due to the potential for stimulation offered by the mechanical properties of the granites, radiogenic heat production, modern tectonic activity, and the thickness of the pluton). The model used in the analysis, which takes into account a hypothetical assessment of the manner and paths of fluid migration within the pluton, provides an insight into the spatial distribution of subsurface temperatures. It thus allows the location of relatively shallow high-temperature zones, which are optimal for the efficient application of HDR technology, to be identified. With respect to this technology, the Szklarska Poręba area and the NE part of the pluton seem to be better targets than the Cieplice central area, where the model indicated much lower temperatures (e.g. at a depth of 5,000 m, estimated temperatures in the vicinity of Szklarska Poręba were about $185^{\circ} \mathrm{C}$ and in the vicinity of Cieplice they were about $140^{\circ} \mathrm{C}$ ).
\end{abstract}

Keywords: HDR technology, Karkonosze Pluton -Poland, structural and thermal model

Celem badań było opracowanie przestrzennego rozkładu temperatur plutonu Karkonoszy dla wskazania optymalnej lokalizacji dla systemu HDR na głębokościach osiągalnych wierceniami.

Geotermalna technologia HDR umożliwia wykorzystanie ciepła wnętrza Ziemi na obszarach pozbawionych płynów termalnych głównie a aspekcie produkcji energii elektrycznej w systemach binarnych. Dla efektywnej pracy takich systemów wymagana jest temperatura górotworu powyżej $100^{\circ} \mathrm{C}$. W artykule

* MINERAL AND ENERGY ECONOMY RESEARCH INSTITUTE OF THE POLISH ACADEMY OF SCIENCES, WYBICKIEGO 7, 31-261 KRAKÓW, POLAND

** AGH UNIVERSITY OF SCIENCE AND TECHNOLOGY, FACULTY OF MINING SURVEYING AND ENVIRONMENTAL ENGINEERING, DEPARTMENT OF ENVIRONMENTAL MANAGEMENT AND PROTECTION, AL. A. MICKIEWICZA 30, 30-059 KRAKOW, POLAND

1 CORRESPONDING AUTHOR: E-MAIL ADDRESS: barbacki@agh.edu.pl 


\begin{abstract}
autorzy analizowali potencjalną możliwość zastosowania technologii HDR na obszarze plutonu Karkonoszy, który potraktowano jako optymalny dla zastosowania systemu HDR - głównie wskutek mechanicznej podatności granitów na procesy sztucznego szczelinowania, wysoką produkcję ciepła radiogenicznego, współczesną aktywność tektoniczną oraz znaczną miąższość plutonu.

Prezentowany, hipotetyczny model strukturalno-termiczny uwzględniający sposób i drogi migrujących płynów pokazuje przestrzenny rozkład wgłębnych temperatur w obrębie plutonu. Umożliwia to lokalizację stref wysokich temperatur położonych względnie płytko, a zatem optymalnych dla efektywnego zastosowania technologii HDR. W tym kontekście, strefa plutonu w rejonie Szklarskiej Poręby oraz jego część NE przedstawiają się korzystniej niż strefa centralna w rejonie Cieplic, gdzie przeprowadzone modelowanie wskazuje temperatury znacznie niższe (np. w strefie Szklarskiej Poręby na głębokości $5000 \mathrm{~m}$ temperatury około $185^{\circ} \mathrm{C}$ natomiast w strefie Cieplic około $140^{\circ} \mathrm{C}$ ).
\end{abstract}

Słowa kluczowe: technologia HDR, Karkonosze, model strukturalno-termiczny, anomalie termiczne

\title{
1. Introduction
}

To increase the energy security of the country it is necessary to consistently carry out activities for the development of alternative energy technologies, both renewable as nuclear (Fraczek et al., 2013). The use of geothermal alternative energy in our country is limited to the exploitation of heat from hot water and rocks for heating purposes (Śliwa at al., 2012). Studies on the production of electricity using the heat of rocks are still pioneering.

Hot Dry Rock (HDR) technology is a geothermal technology to producing electricity using the enthalpy of rocks that are isolated from underground water circulation. In order to produce electricity from an HDR system using binary cycle power plants, temperatures in excess of $100^{\circ} \mathrm{C}$ are required. The issue of modelling the operation of HDR systems in Polish geothermal conditions has already been mentioned in literature on the subject (Miecznik \& Pająk, 2012). Geological targets for HDR technology are usually crystalline rocks occurring at depths of 3-5 km. The operation of HDR systems is often associated with the clogging of injection wells (particulary in Enhanced Geothermal Systems using natural hot brine). Although this process is not the subject of the present investigations, the increase in the injection pressure required creates serious issues during system operation (Bujakowski et al., 2008, Tomaszewska, 2008; Tomaszewska \& Pająk, 2012; 2013a, b). However, owing to the low mineralisation of water in the area of the Sudetes region investigated, these problems should not significantly obstruct the operation of HDR systems located there.

The majority of crystalline rocks suitable for HDR technology in Poland are covered by a thick layer of sedimentary rocks (Fig. 1). However, there are also extensive areas in southern Poland (mainly in the Sudetes Mountains, including the Fore-Sudetic Block) where igneous rocks are found as outcrops and where these rocks are several kilometres thick. Crystalline rocks also occur in the Polish Tatra Mountains, continuing into Slovakia. The remaining areas are either completely or partly covered by Caenozoic or Mesozoic formations.

Large-volume volcanic lava flows of the Sudetes Mountains and the Fore-Sudetic Block are associated with Late Palaeozoic magmatism. The potential utilisation of the heat these rocks may be difficult as large areas in these regions are protected on account of their natural environment. In spite of this we have focused on some areas in the Sudetes Mountains in order to conduct research on the possibilities of using HDR technology in crystalline formations. An essential premise in this respect was also the occurrence of granite plutons that are especially suitable for the application of HDR technology. 


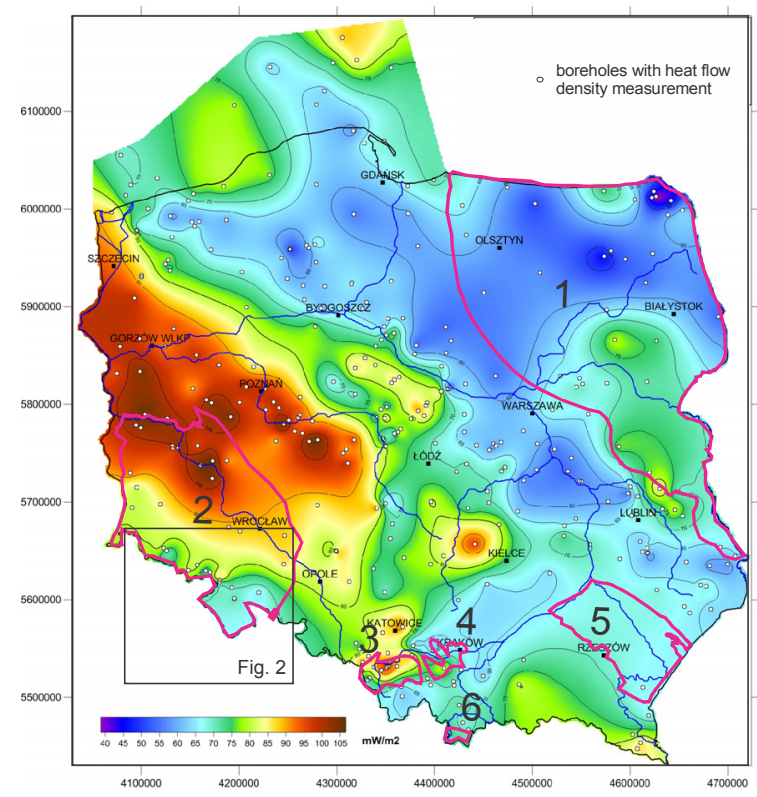

Complexes of crystaline rocks

1. Crystalline basement of NE-Poland

(Precambrian and Old Paleozoic igneous rocks)

2. Sudetes and Fore Sudetic Block

(Precambrian-Old Paleozoic igneous rocks,

Early Paleozoic igneous rocks and

Meso-Cenozoic magmatic rocks

[Lower Silesia basaltic formation])

3. Upper Silesian Massif

(Precambrian and Early Paleozoic igneous rocks)

4. Małopolska Massif

(Precambrian and Early Paleozoic igneous rocks)

5. Lublin Massif

(Precambrian igneous rocks and volcanic rocks

of Paleozoic Platform)

6. Tatra Mountains

(Precambrian igneous rocks, Early Paleozoic igneous rocks and Meso-Cenozoic magmatic rocks)

Fig. 1. Complexes of crystalline formations in Poland at $3000 \mathrm{~m}$ b.s.l. (according to Kotański, 1987; for area 5 according to Dadlez et al., 2000) on the background of the map of the heat flow density

(Szewczyk \& Gientka, 2009)

\section{Crystalline formations of the sudetes mountains in the context of the requirements of hdr technology}

Crystalline rocks in this area (Fig. 2) comprise igneous rocks in plutons, metamorphic rocks (especially those which are adjacent to plutons) and volcanic rocks (especially basalts in volcanic chimneys). The heat of the crystalline rocks originating inside the Earth, can be transmitted to shallow parts of the rocks, predominantly as a result of convection and conduction through deep fractures. A convectional and conductional inflows of heat from deep layers of the Earth were found also in the Sudetes (Dowgiałło, 2000). Studies by Majorowicz (1984), Majorowicz \& Plewa (1977, 1979), S. Plewa (1984) and M. Plewa (1988) provide a wealth of information on radiogenic heat production by rocks in Poland. In the Sudetes region, a significant amount of heat is also generated during the radioactive decay of certain rock-building minerals. Recent studies in the area of Szklarska Poręba (Karkonosze Mountains, Fig. 3) indicate that the average value of radiogenic heat production in granites in this area is high and amounts to ca. $6 \mu \mathrm{W} / \mathrm{m}^{3}$ (according to well core data at depths of up to $200 \mathrm{~m}$ ). These figures are similar to those in the Variscan Erzgebirge pluton where values of $4-10 \mu \mathrm{W} / \mathrm{m}^{3}$ were recorded (Förster \& Förster, 2000).

The Sudetes Mountains and the Fore-Sudetic Block have a different history compared to other areas of igneous rock occurring in Poland. The area has experienced several periods of magmatic events resulting in large intrusive bodies and in several occurrences of volcanic rocks related to delivering of additional amount of heat. 


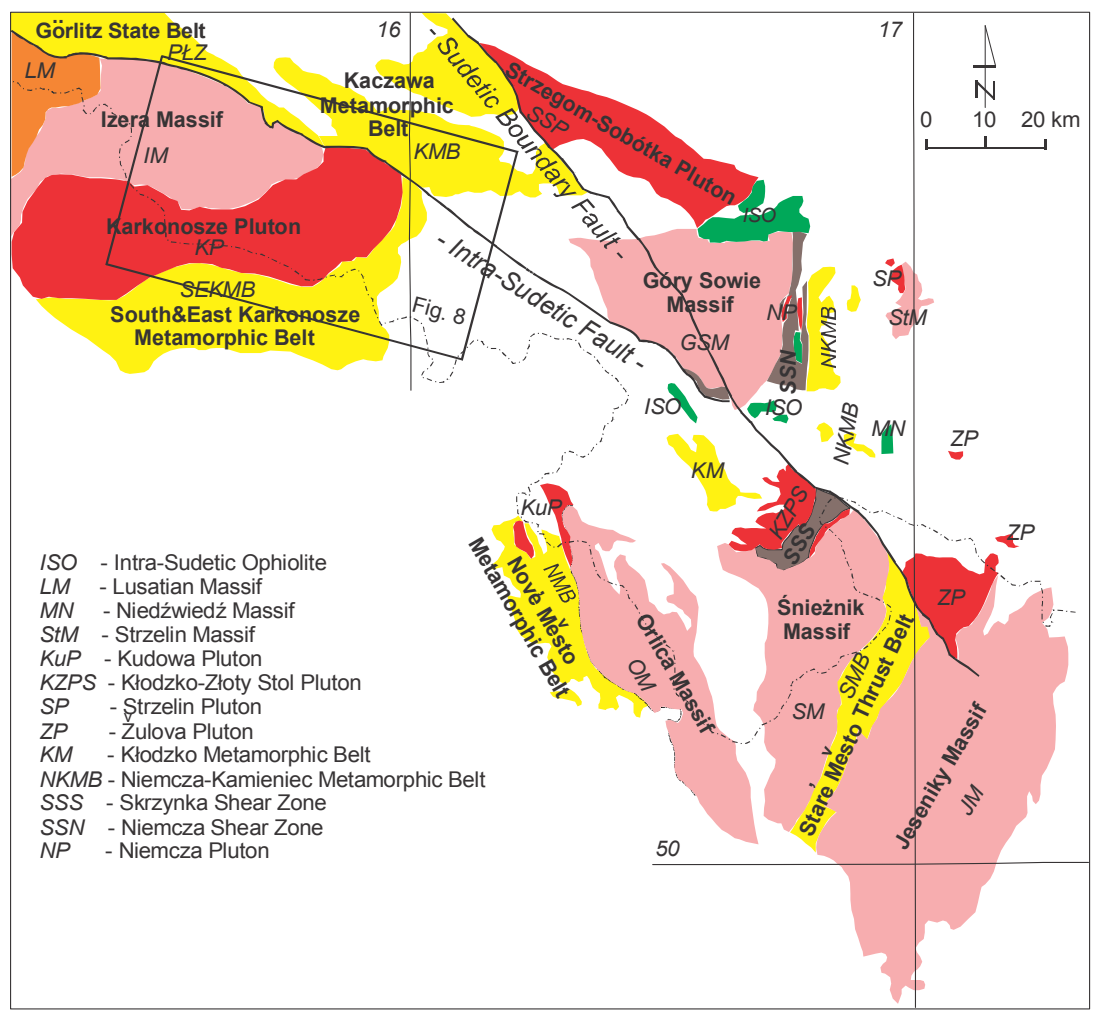

Fig. 2. Structural units of the Sudetes Mountains and the Fore-Sudetic Block containing crystalline formations (without Miocene-Pliocene volcanites of the Lower Silesian basalt formation, after Mazur et al., 2010)

Owing to the dimensions of the plutons and the degree of their tectonic overprints, the most interesting plutons from the viewpoint of applying HDR technology are those that developed close to the end of the Variscan orogeny, when granite plutons were formed. The largest area is occupied by the Karkonosze Pluton. This pluton has a surface area of ca. $185 \mathrm{~km}^{2}$ within the borders of Poland, probably reaching a depth of more than $10 \mathrm{~km}$. This is indicated, inter alia, by the results of gravimetric and magnetic modelling (Żelaźniewicz et al., 1997).

\section{Karkonosze pluton: a potential crystalline structure for the application of hdr technology}

\subsection{Surface geophysical and borehole studies}

Being outside the scope of oil prospecting interests, the Karkonosze area was for a long time not considered a target for full geophysical investigations of its deep geological structure. The gravimetric map available at the regional scale (Fig. 3A) shows strong negative anomalies that also cover the Kaczawa and Izera Mountains regions. In fact, the zone of maximum negative 


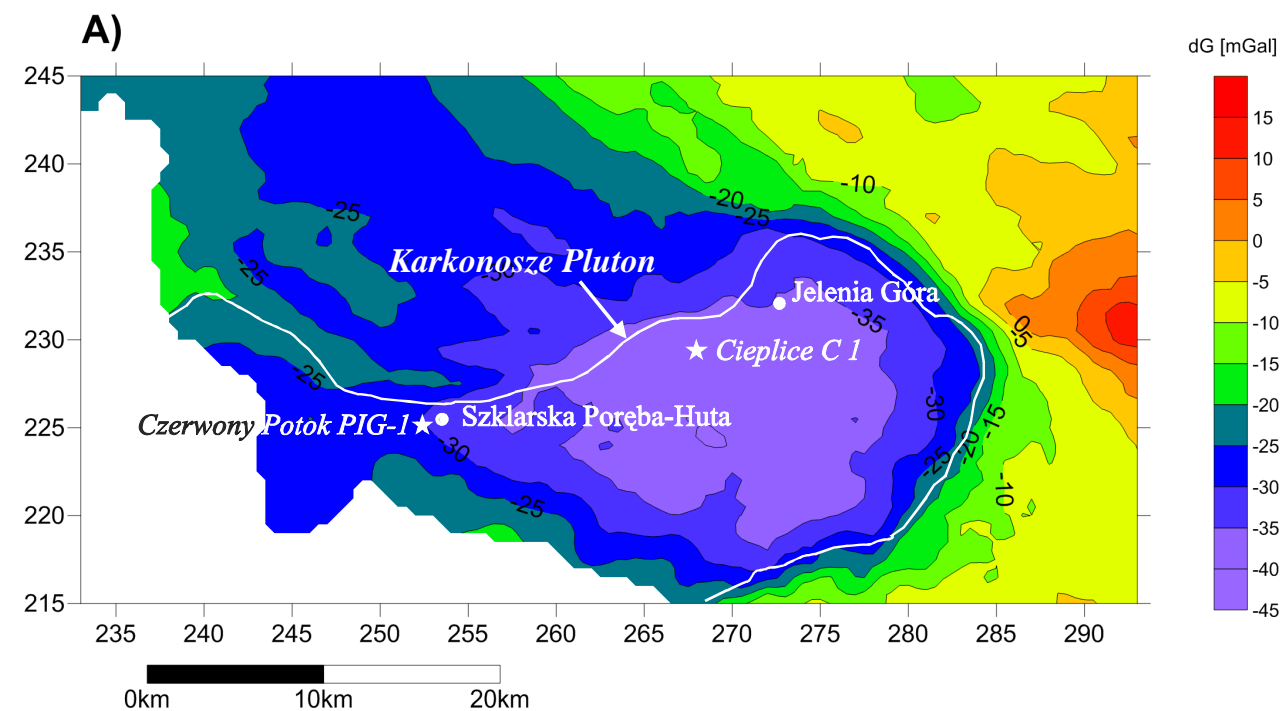

B)

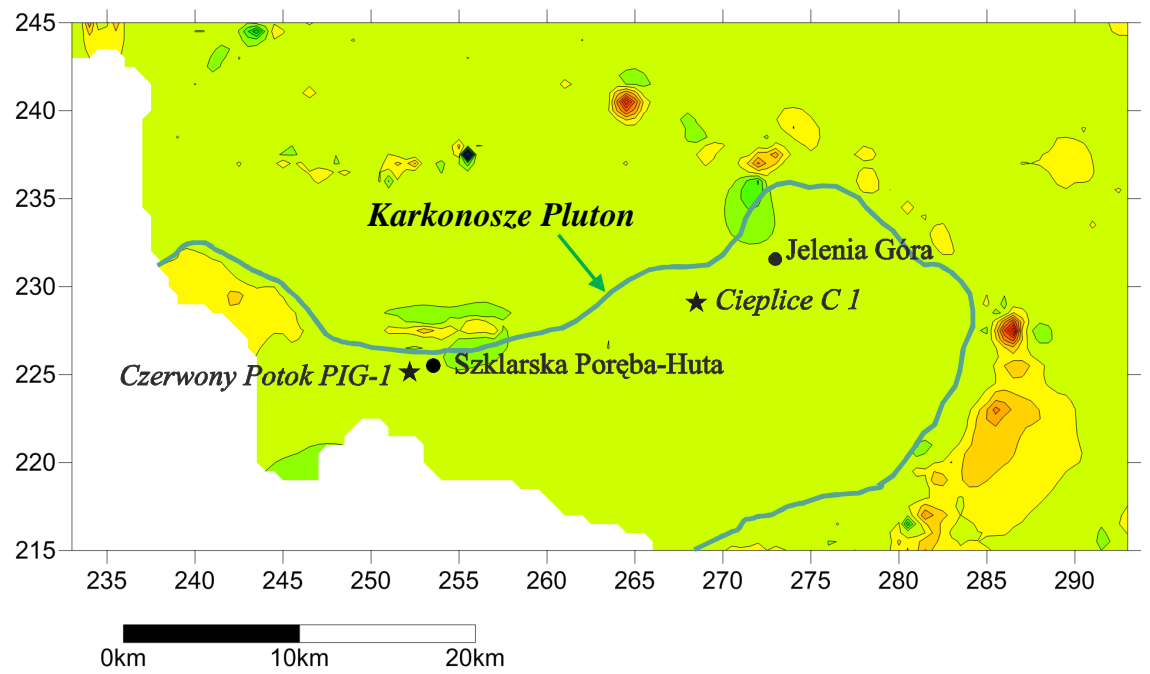

dT [nT]

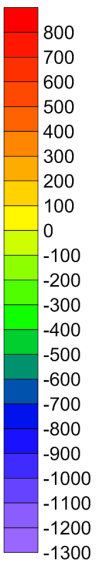

Fig. 3. Karkonosze Pluton: regional maps of the gravimetric [A] and magnetic [B] anomalies, according to the PIG-PIB Warszawa data

values is associated with the eastern segment of the pluton, south of Jelenia Góra. The gravimetric "lightness" of that zone results probable not only from its low density locally related to hydrothermal and autometamorfic processes, but also from the intense fracturing of granites as a results tectonic. It is possible that the zone constituted the main centre of magma eruptions during pluton formation. However, the difficulty associated with accessing more detailed gravimetric data has made it impossible to carry out more detailed analyses. 
The location of the zone identified matches the zone of convective inflow of cool underground waters discussed later in this paper. Waters, which migrate from the elevated recharge areas along numerous fracture and delamination zones are - probably due to a relatively high velocity of water migration - not very hot in deep zones, but relatively hot in shallow ones.

The magnetic anomaly map (Fig. 3B) shows a fairly continuous zone of positive anomalies in the metamorphic cover along the eastern boundary of the pluton, while these are absent in the remaining pluton area. The strongest positive magnetic anomalies are usually associated with mafic igneous rocks (basalt, diabase and gabbro types) and with metamorphosed shales, while granitic rocks show much lower values. Three-dimensional anomalies (point anomalies) also occur. These are aligned and interpreted as being associated with Miocene tectonic features and magmatism (areas of basalt flows that also occur outside of the Karkonosze Pluton or on its boundaries). However, the origins of a strong negative point anomaly located ca. $15 \mathrm{~km}$ north of Szklarska Poręba-Huta have not been ascertained. Local dispersion of magnetic anomaly values of the pluton and its cover reaches ca. $500 \mathrm{nT}$.

In geothermal studies in Poland, geophysical surveys have mainly been deployed in sedimentary rock complexes (Bujakowski et al., 2010; Barbacki, 2010, 2001). However, magnetotelluric measurements for geothermal purposes were also performed in the Szklarska Poręba area in the vicinity of the Czerwony Potok PIG-1 testing borehole (Fig. 4), and preliminary results indicated that the thickness of the Karkonosze granite could exceed 10,000 m here (resistance values were almost constant at $5 * 10^{3} \mathrm{Ohm}$ during magnetotelluric soundings within the 90010,000 m depth interval).

In Karkonosze, there are only four $500 \mathrm{~m}$ boreholes and there are also single $750 \mathrm{~m}, 1000 \mathrm{~m}$ and $2000 \mathrm{~m}$ boreholes (Fig. 4). The C-1 borehole in Cieplice Śląskie-Zdrój is the deepest (TD $2002.5 \mathrm{~m}$ ) in the Karkonosze Pluton, and with respect to thermal data (Fig. 8) it is the deepest in the Sudetes Mountains and the Fore-Sudetic Block as well (Dowgiałło, 2000). Incomplete records of drilling history have, however, meant that hydrogeological and thermal data obtained from the Cieplice C-1 borehole (especially the temperature profiles) are considered controversial.

A new test borehole (Czerwony Potok PIG-1) was drilled only to assess the thermal and petrophysical parameters of Karkonosze granites with a view to the potential application of HDR technology (Bujakowski et al., 2012). The borehole was drilled in the Szklarska Poręba area in a zone considered anhydrous and outside the postulated convection zone. However, the borehole depth $(200 \mathrm{~m})$, which was limited for economic reasons, did not guarantee accurate data, particularly those related to the temperature gradient and radiogenic heat production. The thermal curve (Fig. 8) allowed the evaluation of the average geothermal gradient value in the near-surface zone, which was approximately $3.9^{\circ} \mathrm{C} / 100 \mathrm{~m}$. Concentrations of radioactive elements measured in drill cores indicate that in the near-surface zone, average radiogenic heat production in granites in the area amounts to ca. $3.9 \mathrm{~mW} / \mathrm{m}^{3}$ and gradually increases, reaching $6.9 \mathrm{~mW} / \mathrm{m}^{3}$ at a depth of $200 \mathrm{~m}$ (the bottom of the borehole). Thermal conductivity measurements conducted on cores from the borehole using optical scanning on dry samples show that average thermal conductivity values generally increase with depth from a value of ca. $1.6 \mathrm{~W} / \mathrm{mK}$ at a depth of $10 \mathrm{~m}$ to ca. $3.1 \mathrm{~W} / \mathrm{mK}$ at a depth of $200 \mathrm{~m}$ (at depths below $190 \mathrm{~m}$, values above $4.0 \mathrm{~W} / \mathrm{mK}$ have also been observed).

Assuming an average thermal conductivity of $2.9 \mathrm{~W} / \mathrm{mK}$ and an average geothermal gradient of $3.9^{\circ} \mathrm{C} / 100 \mathrm{~m}$ in the near-surface zone, a surface heat flow density of ca. $113 \mathrm{~mW} / \mathrm{m}^{2}$ is obtained (with the inevitable estimation error). For these surface heat flow and geothermal gradient values, the temperature at a depth of e.g. $10,000 \mathrm{~m}$ within a granite massif (given zero radiogenic heat production) would be around $395^{\circ} \mathrm{C}$ (assuming $13^{\circ} \mathrm{C}$ at a depth of $200 \mathrm{~m}$ in ac- 


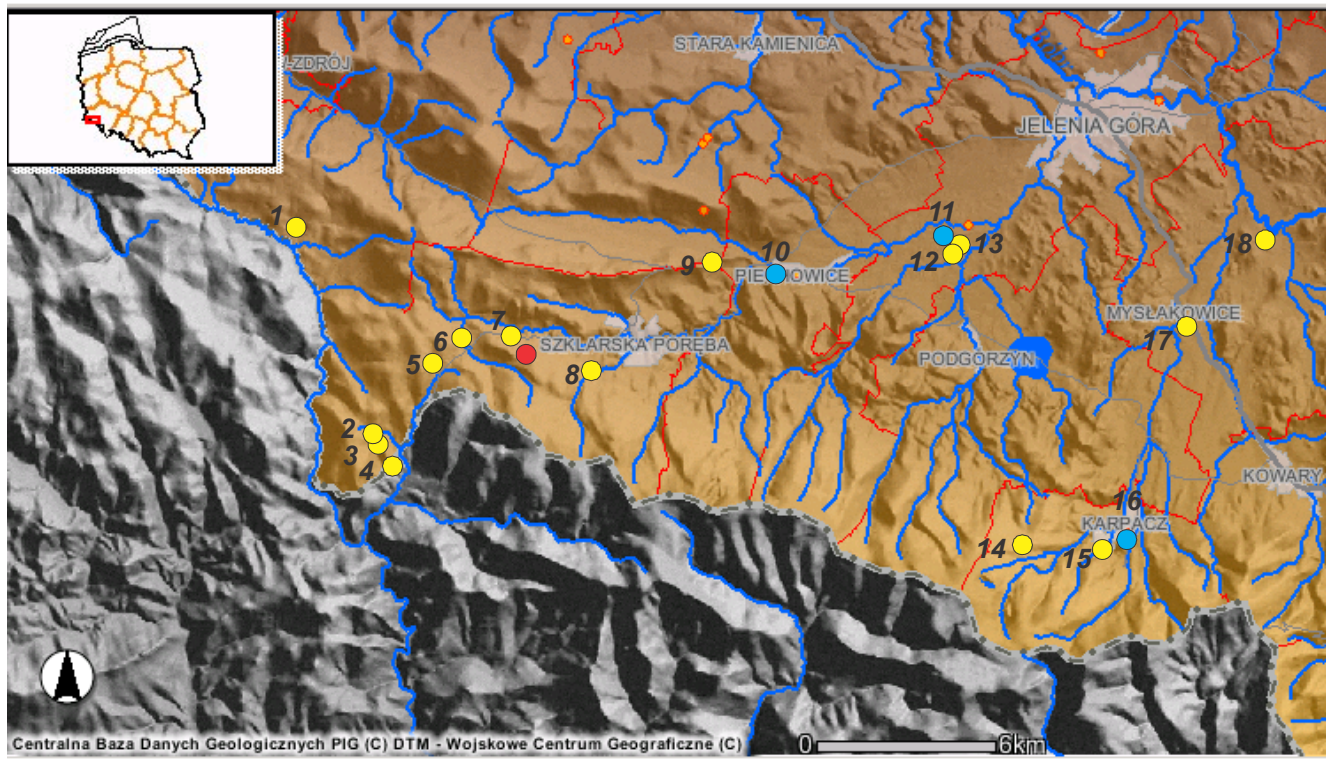

Czerwony Potok PIG-1

boreholes with depth from 50 to $2000 \mathrm{~m}$

boreholes of depth from to up $50 \mathrm{~m}$

\begin{abstract}
Names of boreholes: 1 - Karkonosze IG-7; 2 - Karkonosze J.G.1; 3 - Jakuszyce IG I/1 (4 on sheet Jakuszyce); 4 - Jakuszyce IG II/1 (5 on sheet Jakuszyce); 5 - Karkonosze IG-1 (3 on sheet Jakuszyce); 6 - Jakuszyce KG II (2 on sheet Jakuszyce); 7 - Szklarska Poręba-Huta KG-I (1 on sheet Jakuszyce); 8 - Szklarska Poreba; 9 - Szklarska Poreba-1A; 10 - group: Piechowice-1 and -2 and the other five boreholes Piechowice; 11 - group: Cieplice II, Warnbrunn Śląski, Warnbrunn Śląski from I to IV and from 1 to 4; 12 - Cieplice C-1; 13 - Cieplice C-2; 14 - Karkonosze IG-6; 15 - Karpacz-3; 16 - group Karpacz - 2, 5, 6 and Karpacz - 3A, 5A, 6A; 17 - Karkonosze IG-4; 18 - Karkonosze IG-5
\end{abstract}

Fig. 4. Locations of boreholes on the background of the model area of the Karkonosze Pluton (after: Centralna Baza Danych Geologicznych PIG , DTM - Wojskowe Centrum Geograficzne )

cordance with the thermal log from the Czerwony Potok PIG-1 borehole, Fig. 8). However, the presence of radiogenic heat leads to a gradual decrease in thermal gradient and heat flow with depth (temperature becomes a non-linear function of depth), thus subsurface temperatures that are determined using the linear relationship based on the surface thermal gradient are overstated.

\title{
3.2. Linking petrophysical data
}

Among the three major types of granites that occur in the Karkonosze Pluton, most importance is attached to the central granites (usually medium-grained or coarse-grained rocks, Borkowska, 1966). They are considered the optimum structures for HDR technology owing to their regional distribution, thickness, large degree of isotropy and the mechanical properties of the rocks. Granite resistance of $200-500 \Omega \mathrm{m}$ is assigned to the central granites and a resistance of up to $1500 \Omega \mathrm{m}$ to the crest granites (usually medium-grained or fine-grained rocks - Borkowska, 1966), respectively. These values were measured by Stefaniuk et al. (2008) in the area of Cieplice Śląskie-Zdrój. Low resistance can indicate a considerable degree of granite fracturing. Suggested resistances can be correlated with data on thermal conductivity in granites, but granite saturation 
with water has a significant impact on the nature of this relationship. In laboratory measurements on dry rock samples from Szklarska Poręba, Plewa (1994) determined values in the range from $1.64 \mathrm{~W} / \mathrm{m}^{\circ} \mathrm{C}$ for medium-coarse grained granite to $2.51 \mathrm{~W} / \mathrm{m}^{\circ} \mathrm{C}$ for fine-grained granite. A value of $2.91 \mathrm{~W} / \mathrm{m}^{\circ} \mathrm{C}$ (unpublished study of Dowgiałło, 2011) was determined for dry coarse-grained granite in Cieplice Śląskie-Zdrój (borehole C-1, interval depth of 775-1953 m).

On the other hand, as mentioned earlier, thermal conductivity values measured in the Czerwony Potok PIG-1 borehole indicate a gradual increase in thermal conductivity with depth; starting at $180 \mathrm{~m}$, the values did not fall below $3 \mathrm{~W} / \mathrm{mK}$. In the upper part of the borehole $(0-100 \mathrm{~m})$, it was mainly coarse-grained granite that was present, while in the lower part (100-200 m), medium-grained granite was found.

Measurements concerning the porosity, permeability, density, specific heat and radiogenic heat production of granite formations were also conducted in the borehole in question. Total porosity values in the upper part of the borehole $(0-100 \mathrm{~m})$ range from $3.94 \%$ (near-surface zone) to $0.86 \%$ (lower part of the coarse-grained granite); in the lower part of the borehole $(100-200 \mathrm{~m}$ ) these range from $1.2 \%$ to $0.47 \%$ (medium-grained granites).

Permeability values are highest in the near-surface zone (ca. $2.9 \mathrm{mD}$ ) and decrease gradually with depth to a value of $0.001 \mathrm{mD}$ at a depth of $100 \mathrm{~m}$; this value does not change until the bottom of the borehole is reached.

Granite density ranges from $2.48 \mathrm{~g} / \mathrm{cm}^{3}$ to $2.66 \mathrm{~g} / \mathrm{cm}^{3}$ across the entire borehole profile. Specific heat measurements performed for temperatures ranging from 80 to $160^{\circ} \mathrm{C}$ yielded values in the $0.84-0.95 \mathrm{~kJ} / \mathrm{kgK}$ range.

Radiogenic heat production values were calculated (according to Rybach, 1973) on the basis of concentrations of the radioactive elements $(\mathrm{U}, \mathrm{Th}, \mathrm{K})$ identified in borehole samples. These values, calculated for 10 cores samples taken from depths of 20 to $200 \mathrm{~m}$, ranged from 3.6 to $8.8 \mathrm{~mW} / \mathrm{m}^{3}$; values above $7 \mathrm{~mW} / \mathrm{m}^{3}$ were obtained for four samples.

Avaiable sheets of the Detailed Geological Map of the Sudetes Mountains generally contain limited data about the deep structures of the Karkonosze Pluton. To extend the information on the internal structure of the pluton, two geological cross-sections through the Cieplice ŚlaqskieZdrój area (Fig. 5) and the SE part of pluton (Fig. 6) were developed. Fig. 5 presents a geological cross-section of Chojnik Mount-Cieplice Ślaskie-Zdrój based on data originating from the C-1 borehole profile of Cieplice Śląskie-Zdrój (Dowgiałło, 2000) and the magnetotelluric profiling conducted close to that town (Stefaniuk et al., 2008). Fig. 6 presents a geological cross-section of the Karpniki-Miedziane Skały region, based on Szałamacha (1956) and Bażyński et al. (1986). These data were helpful in developing the structural model of the Karkonosze Pluton.

\section{Conceptual structural-thermal model}

The main objective of the model was to assess the spatial distribution of subsurface pluton temperatures in order to determine the location of high-temperature zones that are suitable for the HDR technology. Numerical modelling was performed using the TOUGH User's Guide software, version 2.0 (Preus et al., 1999).

The structural model adopted for the study area was a $60 \times 40 \times 10 \mathrm{~km} 3 \mathrm{D}$ block of crystalline rocks comprising the pluton studied and its vicinity (Figs. 7 and 11). The inclusion of the vicinity of the pluton studied in the area modelled simplified the modelling procedure since a simple geometrical solid was being analysed. 


\section{Chojnik Mount - Cieplice Śląskie-Zdrój}

\section{SW}

$\stackrel{0+600}{,+,}$

NE

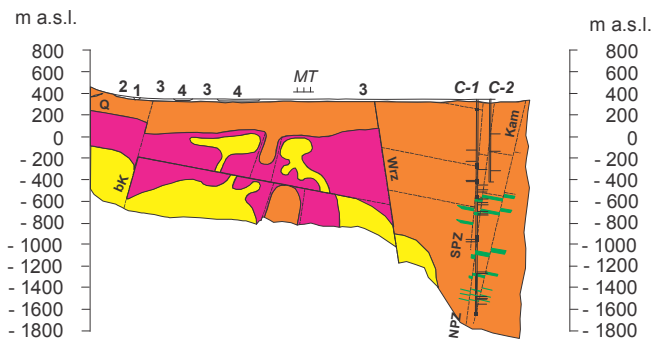

Lower and Middle Carbpniferous:
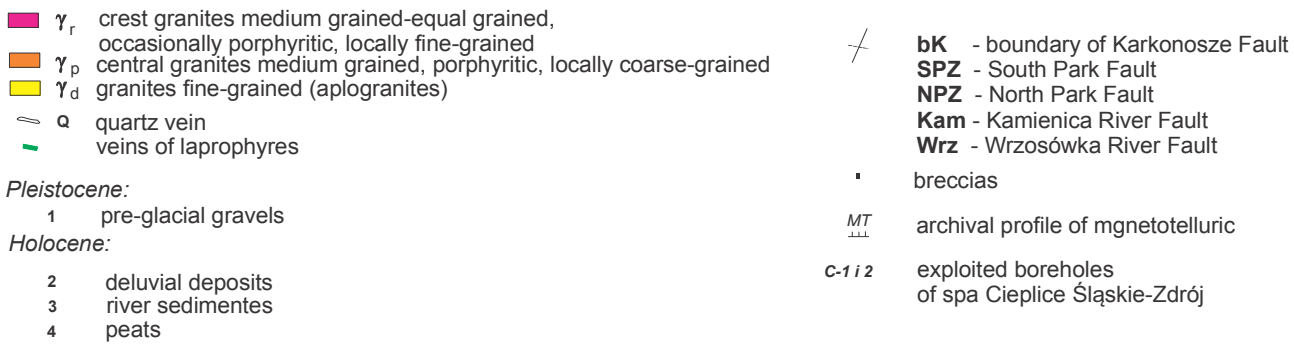

Fig. 5. A geological cross-section through the Cieplice Śląskie-Zdrój area in reference to magnetotelluric profiling (Stefaniuk et al. 2008) and borehole data (Dowgiałło, 2000)

\section{Karpniki - southern slopes of Miedziane Skały}

NWW

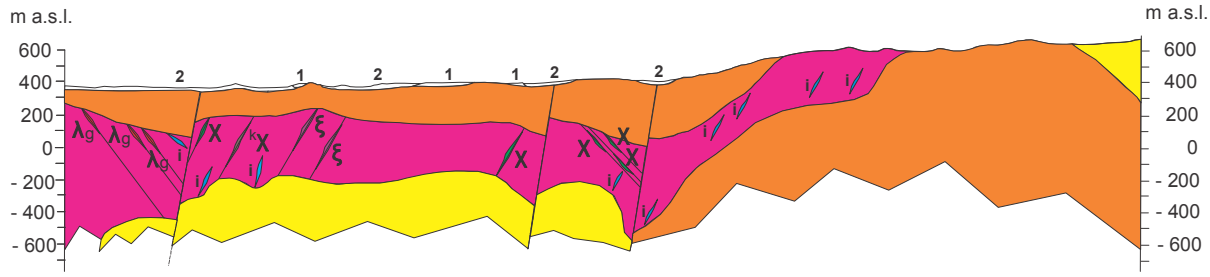

\footnotetext{
Holocene: $\quad 1 \quad$ gravels and sands terrases 4-6 $\mathrm{m}$ anove river level 2 river sedimentes

Lower and Middle Carbpniferous:

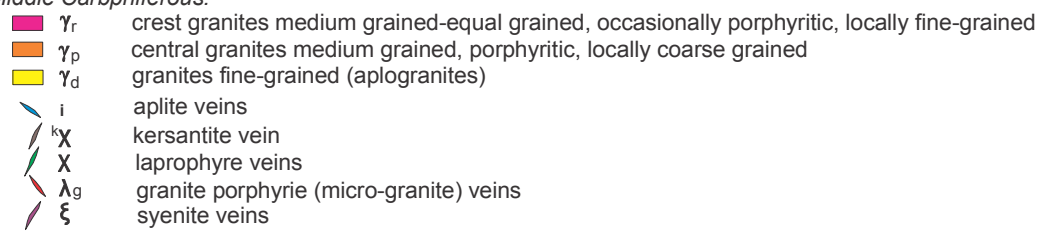

Fig. 6. A geological cross-section of the eastern part of the Karkonosze Pluton, transverse to the local strike; based on the Detailed Geological Map of the Sudetes Mountains, Jelenia Góra Wschód and Janowice Wielkie sheets 


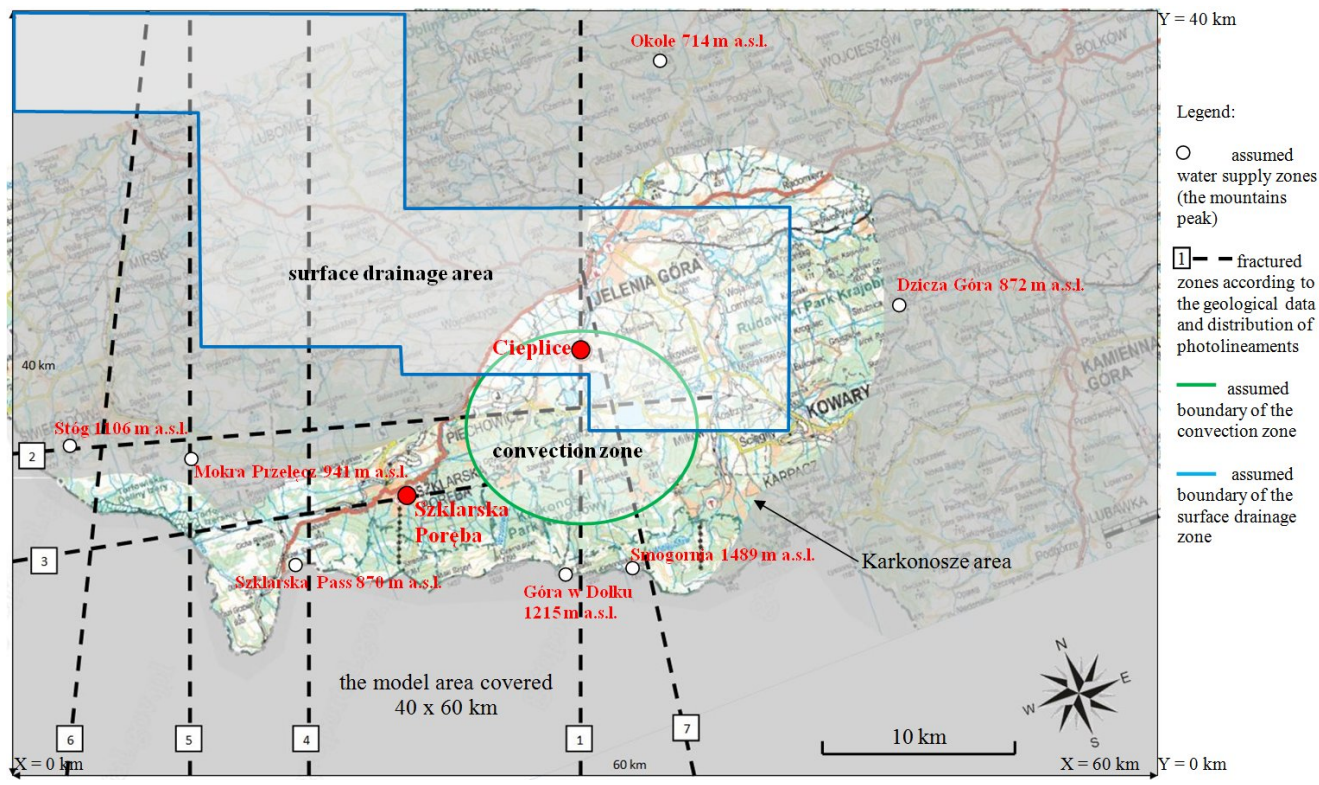

Fig. 7. Surface of the model area $(60 \mathrm{x} 40 \mathrm{~km})$ with deep fractures, convection zones, water supply and drainage zones, and the boundaries of the Karkonosze Pluton within the Polish borders (brighter central zone)

Based on the distribution of major lineaments determined through geological studies and satellite imagery (Bażyński et al., 1986; Skrzypczak, 2011), a network of deep vertical fractures dissecting the pluton was introduced into the block being modelled; it was assumed that some fractures may reach more than $5 \mathrm{~km}$ down (Żelaźniewicz et al., 1997). Owing to the negligible porosity and permeability of granite, these fractures were considered to constitute the main pathways for fluid migration within the pluton.

The analysis of the thermal curve in the Cieplice C-1 borehole (Fig. 8), where a temperature of $65^{\circ} \mathrm{C}$ was recorded at a depth of around $500 \mathrm{~m}$, indicates that a convection zone may be present there. Abnormally high temperatures in the near-surface zone may be the result of the supply of fluids from deep pluton zones via fractured granite formations. The extent of the convection zone on the surface was assumed to coincide with the extensive zone of negative gravimetric anomaly (Fig. 3A) interpreted as a zone where granites are less dense as a result of disintegration and fracturing. It was assumed that the depth of the assumed convection zone may be the same as that of deep fractures.

In a structural model constructed in this manner, fluid migration in the fractures and within the convection zone was an important factor determining the spatial distribution of pluton temperatures.

It was assumed that the main areas of water supply to the pluton are the higher altitudes in the Karkonosze Mountains, from where water is drained by gravity into the pluton and subsequently migrates towards the surface within drainage zones situated in major river valleys (Fig. 7). On the basis of geological data, a 125-metre thick impermeable layer was introduced into the top layer of the model in addition to the supply and drainage zones; its thickness corresponding to the average thickness of silty-clay Tertiary and Quaternary formations. 


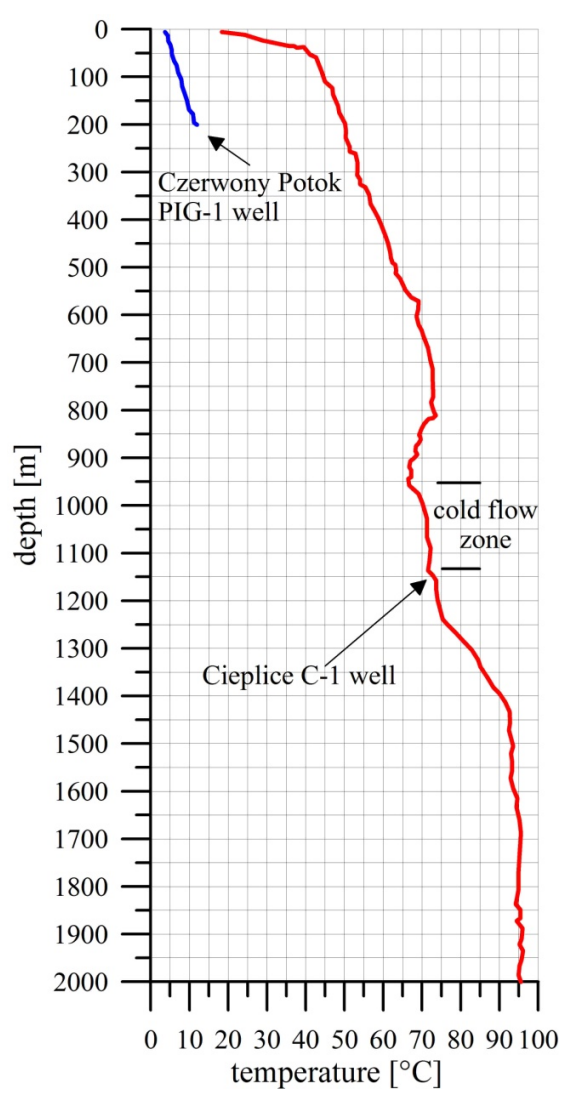

Fig. 8. Thermal log from Cieplice C-1 well (Cieplice Zdrój, after Dowgiałło, 2000) and Czerwony Potok PIG-1 well

(Szklarska Poręba)

Owing to the varied morphology of the area, the top layer of the model block was set at $400 \mathrm{~m}$ a.s.1. (Fig. 11), i.e. the average elevation of the study area. This level was adopted as the reference level for calculations.

The boundary conditions for the top layer of the model block were set by adopting a surface temperature equal to the annual average air temperature, which is $8^{\circ} \mathrm{C}$ in the area. The hydrostatic pressure of the fluid present in the fractures above the top layer of the model was determined in accordance with topography, taking into account a constant atmospheric pressure of $0.1 \mathrm{MPa}$ (Fig. 11).

The bottom layer of the model block was set at a depth of $10 \mathrm{~km}$ b.r.l. (below reference level). The boundary condition for temperature in the bottom layer of the model block resulted from the estimated value of surface heat flow, taking radiogenic heat production into account. Data from the Czerwony Potok PIG-1 borehole indicate that the average value of radiogenic heat production down to a depth of $200 \mathrm{~m}$ amounts to ca. $6 \mu \mathrm{W} / \mathrm{m}^{3}$. It has been assumed that such values persist down to a depth of about $500 \mathrm{~m}$ (the average depth range within which radioactive ores have been found in the Polish Sudetes), and below that level they decrease exponentially with a decay constant $\mathrm{D}=5 \mathrm{~km}$. According to the heat conduction equation with internal heat generation, for measured thermal conductivity near the surface about $2,9 \mathrm{~W} / \mathrm{mK}$ thus for a surface

heat flow estimated to be $113 \mathrm{~mW} / \mathrm{m}^{2}$ at this location - the temperature at a depth of $10 \mathrm{~km}$ b.r.l. ( $10.3 \mathrm{~km}$ below the surface) has been calculated to be $392^{\circ} \mathrm{C}$.

Assuming no radiogenic heat, adopting a surface gradient of $3.9^{\circ} \mathrm{C} / 100 \mathrm{~m}$ and assuming $6^{\circ} \mathrm{C}$ at $8 \mathrm{~m}$ below the surface according to the thermal log from Czerwony Potok PIG-1 well, the temperature at a depth of $10.3 \mathrm{~km}$ would have been ca. $407^{\circ} \mathrm{C}$, i.e. around $15^{\circ} \mathrm{C}$ higher.

As the distribution of concentrations of radioactive elements at greater depths is unknown and the constant $\mathrm{D}$ adopted is hypothetical, a simplification was introduced for the purpose of the calculations in hand, assuming a temperature of ca. $390^{\circ} \mathrm{C}$ at a depth of $10 \mathrm{~km}$ b.r.l., i.e. in the bottom layer of the model.

The initial fluid pressure on the bottom layer of the block being modelled was determined relative to the reference level and hence its value results from the block thickness adopted, i.e. $10 \mathrm{~km}$. After changes in water density associated with the vertical temperature change had been taken into account, neglecting the effect of mineralisation, the initial pressure in the bottom layer 
determined for the entire block being modelled was calculated at $98.8 \mathrm{MPa}$ (Fig. 11) The presence of fluids in zones reaching a depth of about $10 \mathrm{~km}$ is rather hypothetical and only possible within some zones where deep fractures are present.

With these geometric and boundary conditions adopted, the distribution of the thermal and petrophysical parameters determined was fed into the model.

\section{Thermal and petrophysical parameters input into the model}

The thermal and petrophysical parameters of the pluton were obtained and determined on the basis of measurement and archive data.

On the basis of data from the Czerwony Potok PIG-1 borehole, a constant density of granite rocks of $2.6 \mathrm{~g} / \mathrm{cm}^{3}$ and constant specific heat equal to $1 \mathrm{~kJ} / \mathrm{kgK}$ were adopted for the entire block being modelled. As thermal conductivity, which increases with depth, exceeded $3 \mathrm{~W} / \mathrm{mK}$ below $180 \mathrm{~m}$ within this borehole, an average value of this parameter amounting to $3.5 \mathrm{~W} / \mathrm{mK}$ was justified for the entire block used for the model. Values of the aforementioned parameters were assumed to be the same for compact granite zones, granite in drainage zones, within fractures and within the convection zone (Table 1), although this is quite a significant simplification.

TABLE 1

Thermal and petrophysical parameters contributing to the Karkonosze Pluton model

\begin{tabular}{|c|c|c|c|c|c|c|c|c|}
\hline \hline \multirow{2}{*}{ No. } & $\begin{array}{c}\text { Name } \\
\text { of the } \\
\text { material }\end{array}$ & $\begin{array}{c}\text { Effective } \\
\text { porosity }\end{array}$ & Density & \multicolumn{3}{|c|}{$\begin{array}{c}\text { Permeability } \\
{[\mathbf{m D}]}\end{array}$} & $\begin{array}{c}\text { Specific } \\
\text { heat }\end{array}$ & $\begin{array}{c}\text { Thermal } \\
\text { conductivity } \\
\text { coefficient }\end{array}$ \\
\cline { 3 - 9 } & {$[\%]$} & {$\left[\mathbf{k g} / \mathbf{m}^{3}\right]$} & $\mathbf{X}$ & $\mathbf{Y}$ & $\mathbf{Z}$ & {$[\mathbf{k J} / \mathbf{( k g K}]$} & $[\mathbf{W} / \mathbf{m} \mathbf{K})]$ \\
\hline 1 & Granites no fractured & 0.5 & 2600 & 0.01 & 0.01 & $10^{-3}$ & 1 & 3.5 \\
\hline 2 & $\begin{array}{c}\text { Zone } \\
\text { of surface drainage }\end{array}$ & 3 & 2600 & 100 & 100 & 10 & 1 & 3.5 \\
\hline 3 & Fracture 1 & 5 & 2600 & 0.01 & 0.01 & $10^{-3}$ & 1 & 3.5 \\
\hline 4 & Fracture 2 & 10 & 2600 & 100 & 100 & 10 & 1 & 3.5 \\
\hline 5 & Fracture 3 & 5 & 2600 & 10 & 10 & 1 & 1 & 3.5 \\
\hline 6 & Fracture 4 & 5 & 2600 & 10 & 10 & 1 & 1 & 3.5 \\
\hline 7 & Fracture 5 & 5 & 2600 & 10 & 10 & 1 & 1 & 3.5 \\
\hline 8 & Fracture 6 & 5 & 2600 & 10 & 10 & 1 & 1 & 3.5 \\
\hline 9 & Fracture 7 & 5 & 2600 & 100 & 100 & 10 & 1 & 3.5 \\
\hline 10 & $\begin{array}{c}\text { Convection zone in } \\
\text { the Cieplice Śląskie- } \\
\text { Zdrój region }\end{array}$ & 5 & 2600 & 10 & 10 & 1 & 1 & 3.5 \\
\hline
\end{tabular}

However, selecting appropriate reservoir parameters, i.e. porosity and permeability, for the aforementioned zones posed a problem. The values obtained from core samples, including the Czerwony Potok PIG-1 borehole, mostly provided information about the parameters of compact granite. The average effective porosity value for granites was estimated at about $0.5 \%$, while the average vertical permeability was estimated at $0.001 \mathrm{mD}$. Porosity in fracture zones, drainage 
and convection zones and $\mathrm{x}$ and $\mathrm{y}$ horizontal permeability in the aforementioned zones were estimated through an iterative selection of these parameters so as to achieve the best match between model temperature curves and the curves from thermal $\log$ measurements in the Cieplice $\mathrm{C}-1$ and Czerwony Potok PIG-1 boreholes. The reservoir parameters presented in Table 1, which were adjusted using this method, made it possible to fit and extrapolate the curves with the accuracy shown in Figs. 9 and 10.

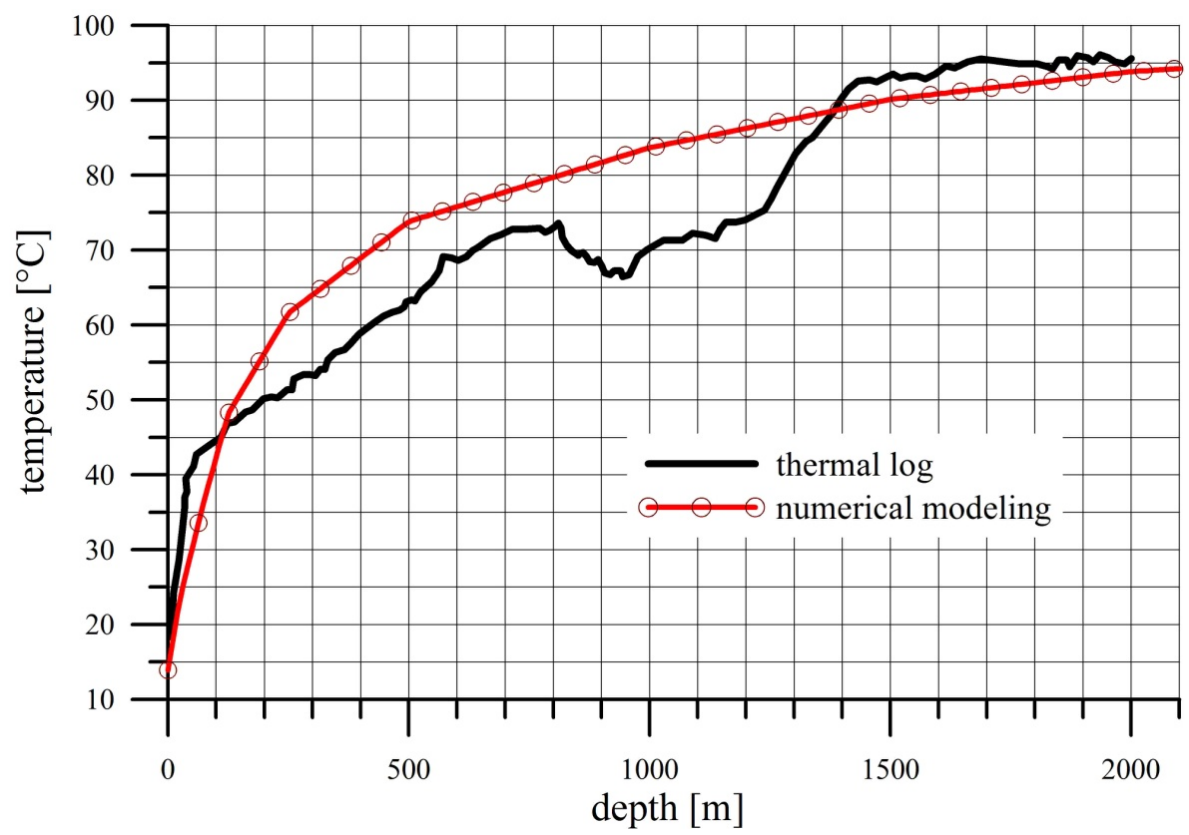

Fig. 9. Comparison of the thermal curve for the Cieplice C-1 borehole with the model curve obtained by iterative matching of the petrophysical and thermal parameters modelled

With a structural-thermal model constructed in this manner, the programme calculates a spatial temperature distribution that is determined both by established petrophysical parameters and the assumed scheme for the migration of underground fluid within the pluton.

\section{Discussion}

As a result of subsequent numerical modelling stages and after model calibration according to the data originating from the Czerwony Potok PIG-1 and Cieplice C-1 boreholes (Fig. 9 and 10), a picture of the distribution of temperatures in the space being modelled was obtained that complied with measurement data. The model is hypothetical and based on a small dataset and thus of questionable credibility.

The results obtained demonstrate that the main direction of intense liquid flow matches the permeable area of fracture 2 (fracture numbering based on Fig. 7). That fracture can probably 


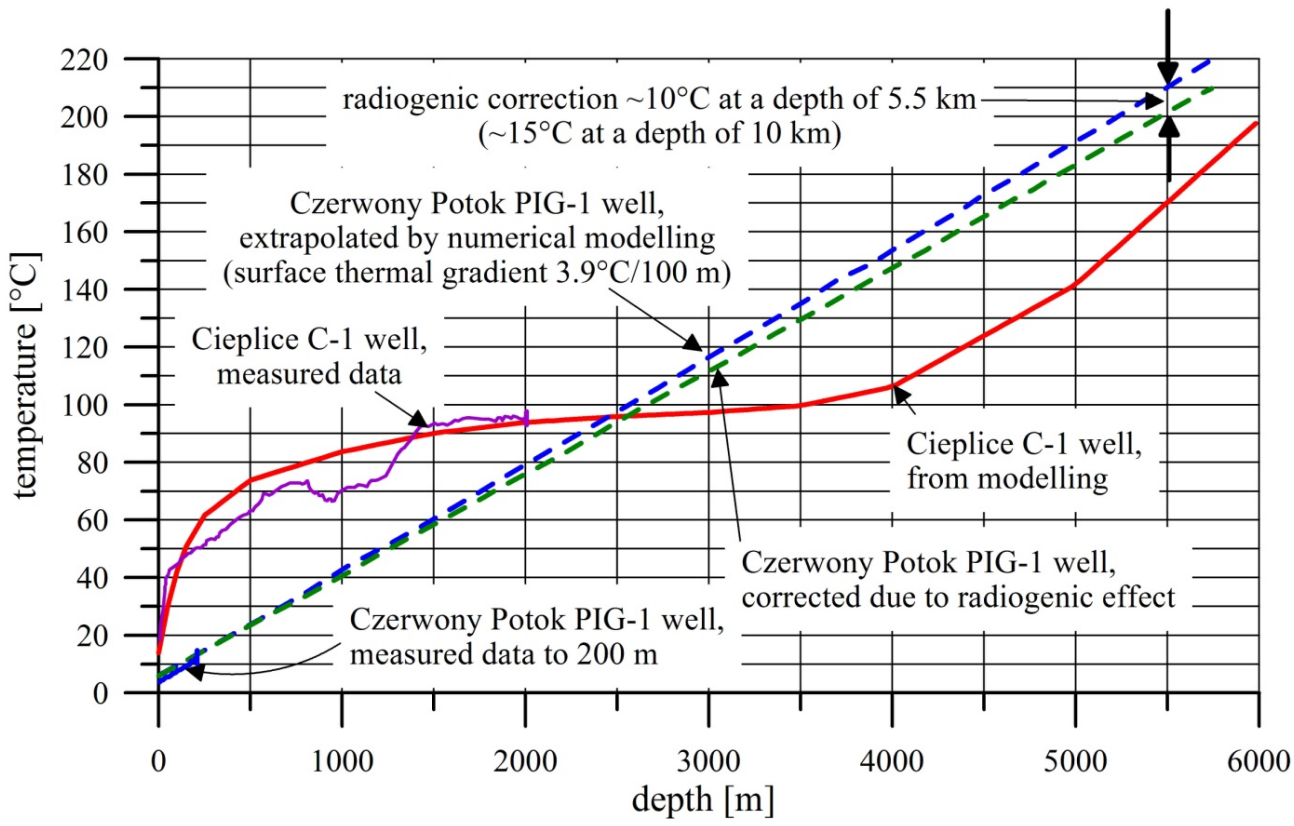

Fig. 10. Comparison of thermal curves produced by the model for the potential conduction zone (Czerwony Potok PIG-1 borehole, Szklarska Poręba) and for the convection zone (Cieplice C-1 borehole, Cieplice Śląskie-Zdrój)

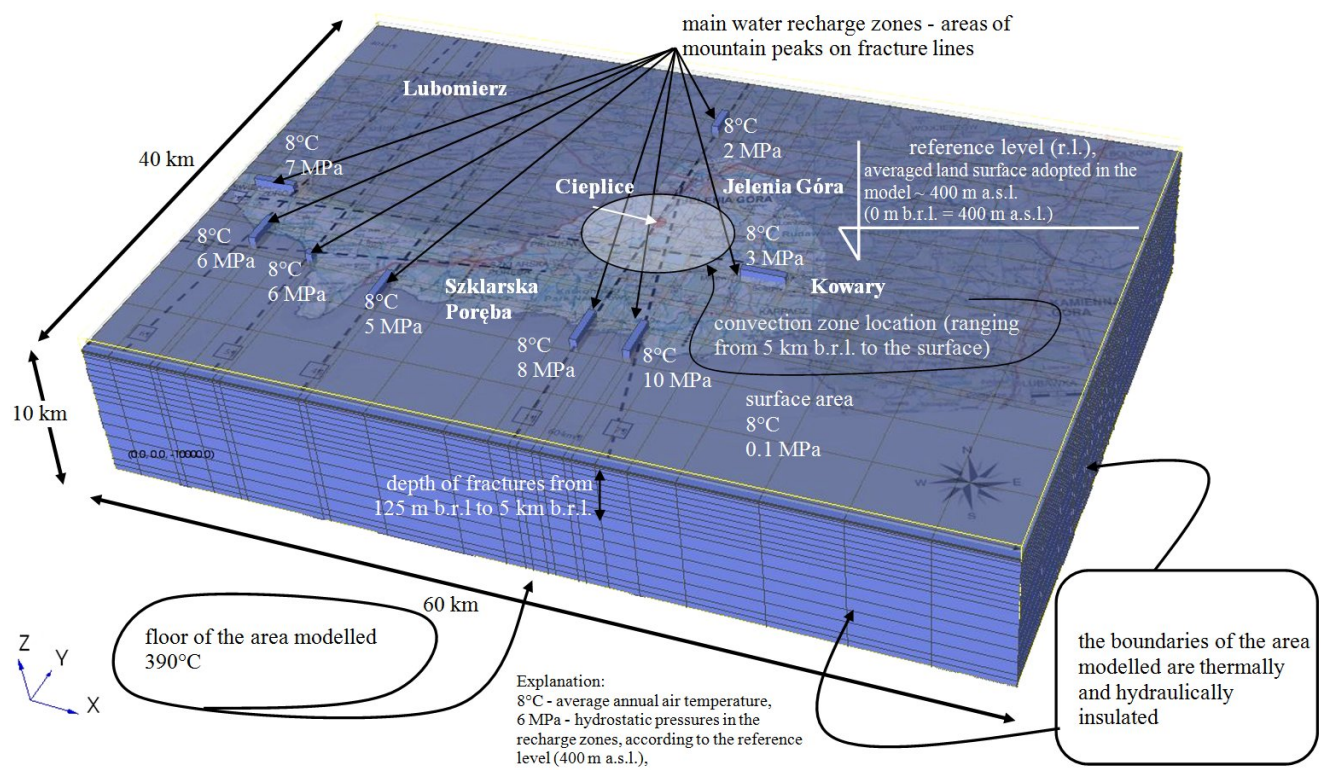

Fig. 11. Discretizaton of the modelled space into elements, with a presentation of the pattern for boundary conditions selection 
be deemed "responsible" for the shallow positive thermal anomaly in the Cieplice Śląskie-Zdrój area, delivering warm waters to the convection area. A less intense and cool inflow from the upper parts of the Karkonosze Mountains via fracture 7 pushes the warm water fed by fracture 2 to the Cieplice Śląskie-Zdrój area.

When the model was tested, no other solution was found with boundary condition assumptions, distribution of fractures and petrophysical parameters that would produce a model compliant with the Cieplice and Szklarska Poręba thermal data as seen in Figs. 9 and 10. The existence of a shallow anomaly in the Cieplice area in the model is also strongly dependent on the presence of the assumed convection and surface drainage areas. Generally, a convection area creates a characteristic thermal curve shape with small changes in temperatures within certain depth intervals (in Cieplice according to the thermal log, this would occur within the $1400 \mathrm{~m}$ to $2000 \mathrm{~m}$ depth interval, with a cooling inflow of cold waters within the interval between $1000 \mathrm{~m}$ and $1300 \mathrm{~m}$, Fig. 8)

Although the postulated convection zone has only been identified in the area of Cieplice, an assumption that it is just a local spot within the entire pluton would not be justified. It has therefore been assumed that its extent on the surface corresponds to the extent of the central zone of negative anomalies observed in gravimetric measurement results.

Although the occurrence of a shallow positive thermal anomaly is assumed for the Cieplice Śląskie-Zdrój area, within the depth interval modelled (up to $10000 \mathrm{~m}$ ) the area is characterised by lowered temperatures below $2500 \mathrm{~m}$. This is shown in Fig. 10 (Cieplice C-1 well), where it can be seen that modelled temperatures below that depth are lower in comparison to the Szklarska Poręba zone (Czerwony Potok PIG-1 well), which was deemed to be a zone where conduction dominated and where the temperature profile nearly corresponded to a straight line. The dynamics and scale of the reduction in temperature within the interval below $2500 \mathrm{~m}$ are the effect of the assumed fracture depth and of the depth reached by the convection zone, which is assumed to be around $5000 \mathrm{~m}$ in the model.

The scale of temperature variation at different depths within individual pluton zones also depends essentially on the assumed fracture depth and on the depth reached by the convection zone in the structural model.

Fig. 12 shows horizontal (A, B, C, D) and the vertical (E) temperature cross-sections of the Karkonosze Pluton for four different depths: 3000 m, 4000 m, $5000 \mathrm{~m}$ and $6000 \mathrm{~m}$ (three additional cross-sections from shallower zones have been shown for the vertical cross-section). Temperature distribution has only been shown for the Polish part of the Karkonosze Pluton, without its surroundings. In Fig. 12E, a positive Cieplice thermal anomaly at depths of up to $2 \mathrm{~km}$, and a negative one below $3 \mathrm{~km}$ can clearly be seen. The largest difference in temperatures between the Cieplice and Szklarska Poręba zones can be observed at depths between $4000 \mathrm{~m}$ and $5000 \mathrm{~m}\left(44-43^{\circ} \mathrm{C}\right)$, but it should be noted that Fig. 12 only shows a qualitative data and not a quantitative one. Horizontal cross-sections demonstrate that this difference would be larger in the area south of Cieplice, in the centre of the assumed convection zone.

The cross-sections presented show that the most promising pluton zones with respect to the application of the HDR technology can be found in the vicinity of Szklarska Poręba and in the NW part of the pluton. However, owing to the very limited amount of well logging data, the evaluation of the NE zone remains purely hypothetical for now. 

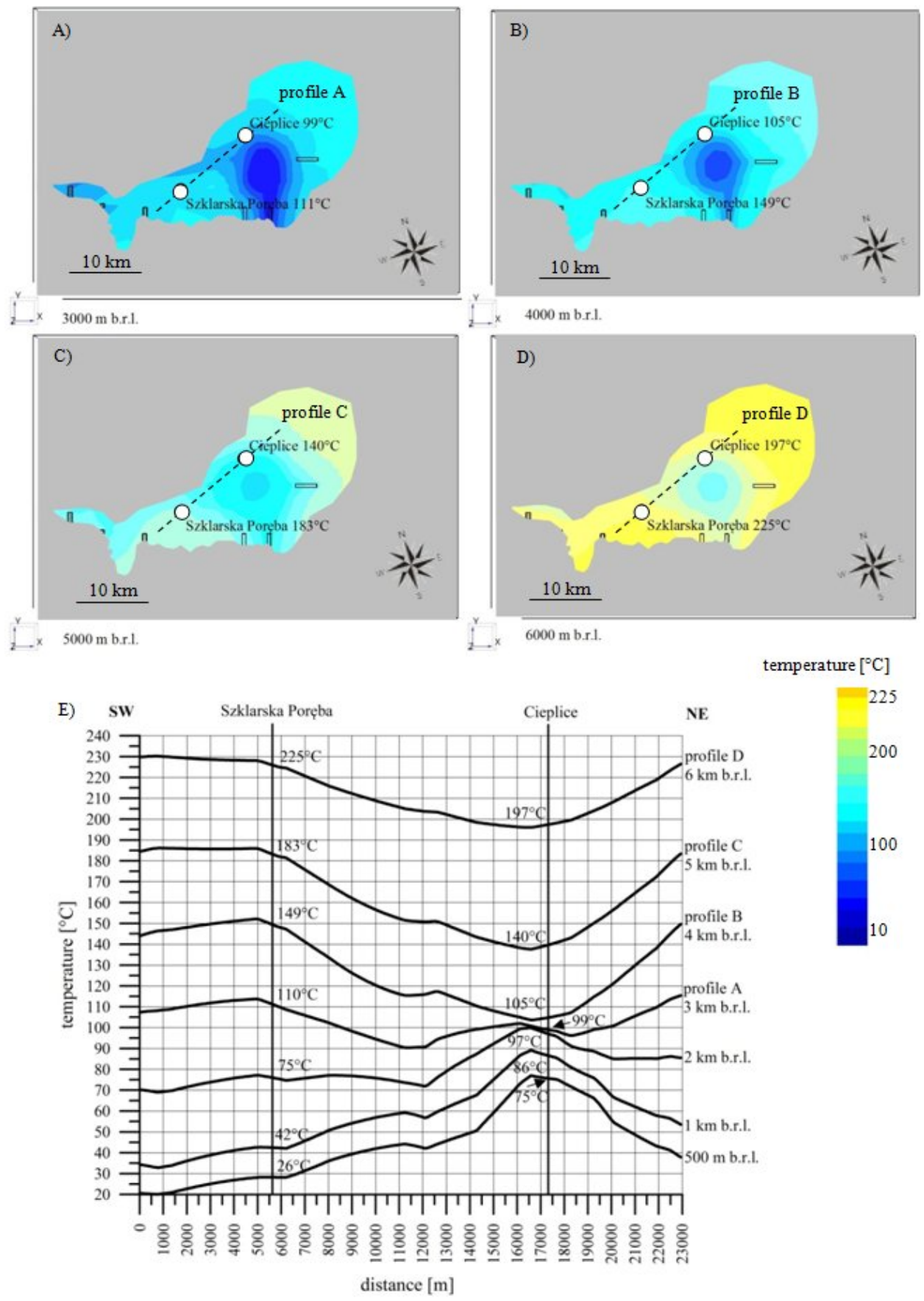

Fig. 12. Results of pluton thermal modelling in the form of horizontal cross-sections (A, B, C and D, sections at depths of $3000,4000,5000$ and $6000 \mathrm{~m}$ ) and a vertical cross-section (E); (in the horizontal cross-sections, only that part of the Karkonosze Pluton in Poland is shown) 


\section{Conclusions}

In view of the present and future use of geothermal energy in Poland, research in this field is directed mainly at thermal energy production (Bujakowski, 2010; Barbacki, 2012). That, however, does not mean that it is not possible to produce electricity based on HDR technology and binary cycle systems, especially in the area of the granite Karkonosze Pluton.

A model was prepared that describes the geothermal conditions of the Karkonosze Pluton and covers an area of $2400 \mathrm{~km}^{2}(40 \times 60 \mathrm{~km})$. The locations of major deep tectonic fissures and that of the convection zone in the area modelled were assumed.

The model presented offers only one of the possible hypotheses which explain the spatial distribution of pluton temperatures on the basis of very limited well data. Therefore the suggestion that the Szklarska Poręba and NE pluton areas appear more promising for HDR technology than the Cieplice-Zdrój area and the area south of Cieplice requires thorough verification. This verification should mostly concern the confirmation of the presence and depth of the convection zone and the extent and location of major fractures in the pluton as well as involving the obtaining of reliable petrophysical data from a borehole with a depth of at least $3000 \mathrm{~m}$ (with the possibility of drilling further). In conclusion, a deep borehole would have to be drilled in the designated pluton area (e.g. in the Szklarska Poręba zone preliminarily indicated by the aforementioned considerations) and a wide range of gravimetric and magnetotelluric surveys would have to be conducted in its vicinity (within a radius of at least $1 \mathrm{~km}$, i.e. the zone for a potential reinjection well). Seismic surveys, even those conducted using 3-D techniques, may prove very difficult to interpret owing to the peculiar structural features of the pluton. Irrespective of the weaknesses of the model presented and of many of its assumptions, the indication that the pluton is the optimum structure for testing the HDR technology in Poland appears quite reasonable. The inclusion of numerous categories of data (geological, geophysical, petrophysical and satellite) in the analysis also suggests that despite its considerable simplifications, the model offers a spatial image of the pluton thermal properties that is hypothetical but reasonable at the same time.

\section{ACKNOWLEDGEMENTS}

Acknowledgements for assistance in the preparation of this paper are due to the Consortium of PIG PIB Warsaw, PPG Warsaw, AGH Kraków and IGSMiE PAN Kraków that carried out the project entitled Evaluation of the Potential, Thermal Balance, and Prospective Geological Structures in Respect of the Needs of Closed Geothermal Systems (Hot Dry Rocks) in Poland, ordered by the Polish Ministry of the Environment and financed from NFOŚiGW funds (2010-2013).

\section{References}

Barbacki A., 2012. Classification of geothermal resources in Poland by exergy analysis-comparative study. Renewable and Sustainable Energy Reviews, 16 (1): 123-128.

Barbacki A., 2010. Geological and technical aspects of geothermal energy utilization in South-East Poland. Environment Protection Engineering, 36 (1):25-34.

Barbacki A., 2001. Middle Jurassic geothermal formation in central part of the Carpathian Foredeep and neighboring areas (Southern Poland). Przegląd Geologiczny, vol. 49, nr. 10/1, p. 894-900. 
Bażyński J., Graniczny M., Oberc J., Wilczyński M.S., 1986. Photogeological Map of Sudety Mountains 1:200 000. Wydawnictwa Geologiczne, Warszawa.

Borkowska M., 1966. Petrografia granitu Karkonoszy. Geologia Sudetica, 2: 7-119.

Bujakowski W., 2010. The use of geothermal waters in Poland (state in 2009) (in Polish with English summary). Przegląd Geologiczny, 58 (7): 580-588.

Bujakowski W., Barbacki A., Czerwińska B., Pająk L., Pussak M., Stefaniuk M., Trześniowski Z., 2010. Integrated seismic and magnetotelluric exploration of the Skierniewice, Poland, geothermal test site. Geothermics, 39 (1): 78-93.

Bujakowski W., Barbacki A.P., Skrzypczak R., Kasztelewicz A., 2012. Exploratory drilling planned for modelling of hot dry rock (HDR) geothermal system in the Karkonosze Mts. (in Polish with English summary). Przegląd Geologiczny, 60 (4): 199-205.

Bujakowski W., Pająk L., Tomaszewska B., 2008. Renewable energy resources in the Silesian Voivodship (Southern Poland) and their potential utilization. Mineral Resources Management, 24 (2): 409-426.

Centralna Baza Danych Geologicznych PIG. 2010, PIG Warszawa.

http://geoportal.pgi.gov.pl/portal/page/portal/cbdg . 2010-03-13.

Dadlez R., Marek S., Pokorski J., 2000. Mapa geologiczna Polski bez utworów kenozoiku 1: 1000 000. Państwowy Instytut Geologiczny, Warszawa.

Dowgiałło J., 2000. Thermal water prospecting results at Jelenia Góra-Cieplice (Sudetes, Poland) versus geothermometric forecasts. Environmental Geology, 39 (5): 433-436. Springer-Verlag.

Förster A., Förster H-J., 2000. Crustal composition and mantle heat flow: Implications from surface heat flow and radiogenic heat production in the Variscan Erzgebirge (Germany). Journal of Geophysical Research, vol. 105, No B12, p. 27,917-27,938.

Frączek P., Kaliski M., Siemek., 2013. The modernization of the energy sector in Poland vs. Poland's energy security. Archives of Mining Sciences. Vol. 58, No 2, p. 301-316.

Kotański Z., 1987. Geologiczna kartografia wgłębna. Wydawnictwa Geologiczne, Warszawa.

Majorowicz J., 1984. Problem of Tectonic Interpretation of Geothermal Field Distribution in the Platform Areas of Poland. Publications of the Institute of Geophysics, Polish Academy of Science, Journal A-13 (160)

Majorowicz J., Plewa S., 1977. The Results of Surface Heat Flow Investigation of the Earth Performed in Poland. Publications of the Institute of Geophysics, Polish Academy of Science, Journal A-3 (103)

Majorowicz J., Plewa S.,1979. Study of Heat Flow in Poland with Special Regard to Tectonophysical Problems. [In:] Terrestial Heat Flow in Europe, V. Čermak, Rybach L. (eds), Springer Verlag, Berlin, pp: 240-252

Mazur S., Aleksandrowski P., Szczepański J., 2010. Outline structure and tectonic evolution of the Variscian Sudetes. Przegląd Geologiczny, 58 (2):133-145.

Miecznik M., Pająk L., 2012. Review of processes taking place in HDR systems in the context of numerical modeling of the results. (in Polish with English summary). Biuletyn Państwowego Instytutu Geologicznego, 448 (1): $247-250$.

Plewa M., 1988. Analiza zmian gęstości powierzchniowego strumienia cieplnego ziemi na obszarze Polski. Zeszyty Naukowe AGH Geofizyka Stosowana, z.1: 109-122.

Plewa S., 1994. Distribution of geothermal parameters on the territory of Poland. (in Polish with English summary). Wydawnictwo Centrum Podstawowych Problemów Gospodarki Surowcami Mineralnymi i Energią PAN, Kraków.

Preuss K., Oldenburg C., Moridis G., 1999. TOUGH2 User `s Guide. Version 2.0 Lawrence Berkley National Laboratory, California.

Rybach L., 1973. Wärmeproduktionsbestimmungen an Gestein der Schweizer Alpen. Beitr. Geol. Schweiz, Geotechn. Ser. Lfg. 51, Kümmerly\&Frey, Bern.

Skrzypczak R., 2010. Igneous and metamorphic rocks of Sudetes and their Foreland-implication for the hot dry rock (HDR) technology. (in Polish with English summary). Technika Poszukiwań Geologicznych, Geotermia, Zrównoważony Rozwój, 49 (1-2): 99-116.

Skrzypczak R., 2011. Propositions for locations of research for geothermal hot dry rock technology in the Sudety region. (in Polish with English summary). Technika Poszukiwań Geologicznych, Geotermia, Zrównoważony Rozwój, 50 (1-2): 93-108.

Stefaniuk M., Czerwiński T., Klityński W., Wojdyła M., 2008. Zastosowanie metody magnetotellurycznych profilowań ciagtych $w$ badaniach strukturalnych. Geologia, 34: 60-64. 
Szałamacha J., 1956. Janowice Wielkie M33-44Bd, arkusz Szczegółowej Mapy Geologicznej Sudetów 1:25 000. Instytut Geologiczny.

Szałamacha M., Tucholska K., 1957. Jelenia Góra Wschód M33-44Bc, arkusz Szczegółowej Mapy Geologicznej Sudetów 1:25 000. Instytut Geologiczny.

Szewczyk J., Gientka D., 2009. Mapa gęstości ziemskiego strumienia cieplnego Polski. PIG Warszawa. www.pig.gov.pl.

Śliwa T., Gołaś A., Wołoszyn J., Gonet A., 2012. Numerical model of borehole heat exchanger in ANSYS CFX software. Archives of Mining Sciences. Vol. 57, No 2, p. 375-390.

Tomaszewska B., 2008. The prognosis of scaling phenomena in geothermal system using the geochemical modeling methods. (in Polish with English summary). Gospodarka Surowcami Mineralnymi, 24 (2/3): 399-407.

Tomaszewska B., Pająk L.,2012. Dynamics of clogging processes in injection wells used to pump highly mineralized thermal waters into the sandstone structures lying under the Polish Lowlands. Archives of Environmental Protection, 38 (3): 105-117.

Tomaszewska B., Pająk L., 2013a. Using Treated Geothermal Water to Replenish Network Water Losses in a District Heating System. Polish Journal of Environmental Studies, 22 (1): 249-256.

Tomaszewska B., Pająk L., 2013b. Cooled and desalinated thermal water utilization in the Podhale Heating System. (in Polish with English summary). Gospodarka Surowcami Mineralnymi, 29 (1): 127-139.

www.geoportal.gov.pl

Żelaźniewicz A., Cwojdziński S., England R., Zientara P., 1997. Variscides in the Sudetes and the reworked Cadomian orogen: evidence from the GB-2A seismic reflection profiling in southwestern Poland. Geological Quarterly, 41 (3): 289-308. 